\title{
GMR
}

\section{Fertility restoration locus and cytoplasm types in onion}

\author{
R.R. Ferreira ${ }^{1}$, C.A.F. Santos ${ }^{2}$ and V.R. Oliveira ${ }^{3}$ \\ ${ }^{1}$ Programa de Pós-Graduação em Agronomia - Melhoramento Genético de Plantas, \\ Universidade Federal Rural de Pernambuco, Recife, PE, Brasil \\ ${ }^{2}$ Centro de Pesquisa Agropecuária do Trópico Semiárido, Petrolina, PE, Brasil \\ ${ }^{3}$ Centro Nacional de Pesquisas de Hortaliças, Brasília, DF, Brasil \\ Corresponding author: R.R. Ferreira \\ E-mail: robertarochaf@hotmail.com \\ Genet. Mol. Res. 16 (3): gmr16039766 \\ Received June 28, 2017 \\ Accepted August 25, 2017 \\ Published September 21, 2017 \\ DOI http://dx.doi.org/10.4238/gmr16039766
}

Copyright (C) 2017 The Authors. This is an open-access article distributed under the terms of the Creative Commons Attribution ShareAlike (CC BY-SA) 4.0 License.

\begin{abstract}
The objective of this study was the identification of the cytoplasmic types and the genotyping for the fertility restoration nuclear locus $(M s)$ in 59 onion accessions, aiming at the selection of ' $\mathrm{A}$ ' and 'B' lines essential for the obtainment of hybrids. Three markers were used to identify the cytoplasm 5' cob, orfA501, and orf725, and two were used for the Ms locus (AcSKP1 and AcPMS1). The two types of male-sterile cytoplasm ('S' and ' $T$ '), as well as fertile cytoplasm ('N'), and the $M s$ and $m s$ alleles in both homozygosity and heterozygosity were detected in the 59 genotypes evaluated in the experiment. The frequencies of the 5' cob/orfA501 and orf 725 markers, as well as of the markers AcSKP1 and AcPMS1, were close in the onion accessions evaluated in this study. In the Brazilian germplasm, the frequencies of the ' $\mathrm{N}$ ', ' $\mathrm{S}$ ', and ' $\mathrm{T}$ ' cytoplasm were approximately $0.47,0.28$, and 0.25 , respectively, whereas the allele frequencies of $M s$ and $m s$ were 0.52 and 0.48, respectively. The accessions Régia, EHCEB 20146, EHCEB 201427, Alvorada, Serrana, Crioula Mercosul, EHCEB 20142, BRS 367, Rainha, Juporanga, and Alfa SF C-XI have potential for the
\end{abstract}

Genetics and Molecular Research 16 (3): gmr16039766 
identification of 'A' and 'B' lines, since they presented mixtures of cytoplasm and different allele frequencies for $M s$. All the plants of the accessions EHCEB 20142040/EHCEB 20141040, EHCEB 20142028/ EHCEB 20141028, and EHCEB 20112006/EHCEB 20111006 were in the Nmsms and Smsms conditions, and have the potential for ' $\mathrm{B}$ ' and ' $\mathrm{A}$ ' lines, respectively, for the CMS-S system. All the plants of the accessions EHCEB 20142027/EHCEB 20141027, EHCEB 20102019/ EHCEB 20101019, and Alfa SF 'B'/Alfa SF 'A' were in Nmsms and Tmsms conditions, and have the potential for ' $\mathrm{B}$ ' and ' $\mathrm{A}$ ' lines, respectively, for the CMS-T system.

Key words: Allium cepa; Maintainer lines; Male-sterile cytoplasm; Hybrid

\section{INTRODUCTION}

Onion is one of the main vegetables in Brazil, accounting for almost 1.5 million tons in the 2015 harvest. The Northeast region is responsible for approximately $20 \%$ of the national production (Leite, 2012; IBGE, 2015). The country accounts for almost 2 and $40 \%$ of the world's and South America's production, respectively, being the 11th largest producer in the world (FAOSTAT, 2017). Despite the high yield, uniformity, and earliness of the hybrids, the use of open-pollinated (OP) populations is significant in some regions, such as in the Northeast region (Nunes et al., 2014). For Santos et al. (2012), the use of OPs is due to the high cost of hybrid seeds, while Nunes et al. (2014) attributed it to the poor dissemination of the agronomic performance of hybrids.

For the production of onion hybrid seeds, the CMS-S and CMS-T systems of nuclearcytoplasmic sterility are used. The first is the most widely used, due to its great stability in the different environments (Havey, 2000). In the CMS-S system, only one gene (Ms) restores fertility, while alleles of three genes restore fertility in the CMS-T system (Kim et al., 2015). For the production of hybrids, male-sterile lines are required ('A' or Smsms lines in the CMS-S system), as well as maintainer lines ('B' or Nmsms lines in the CMS-S system) and lines with combining abilities (lines 'C') (Santos et al., 2008).

The conventional development of onion hybrids requires 4-8 years for cytoplasm identification and 10-12 years for genome transfer by backcrossing (Khosa et al., 2016), considering the biennial cycle of the species. In tropical regions, such as the Brazilian Northeast, this time can be reduced by $50 \%$, since the seed-to-seed cycle is annual, with the vernalization of bulbs in a cold chamber (Santos et al., 2012).

The identification of the fertile (' $N$ ') and sterile cytoplasm ('S' and ' $T$ ') was facilitated and accelerated with the development of the molecular markers 5' cob and orfA501 (Sato, 1998; Engelke et al., 2003), which require two independent polymerase chain reactions (PCR), and of the marker orf725 (Kim et al., 2009), which requires only one PCR. Despite the advance in the cytoplasmic identification, the identification of the ' $\mathrm{B}$ ' line was dependent on manual backcrosses in the field. Identification of the cytoplasm type was performed by Ragassi et al. (2010) and Santos et al. (2012), in predominantly Brazilian germplasm, and by Khar and Saini (2016) in Indian germplasm.

Huo et al. (2015) and Kim et al. (2015) reported the development of markers for

Genetics and Molecular Research 16 (3): gmr16039766 
identification of the male-sterility restorer nuclear locus $(M S)$ making it possible to fully identify 'A' and 'B' lines assisted by markers. Khar and Saini (2016) reported the application of 5' cob and orf 725 markers associated with $M s$ locus markers in Indian germplasm, and no similar study was found in the literature for Brazilian germplasm. Santos et al. (2012) reported experimental hybrids based on the onion 'Baia' germplasm, considering the molecular identification of the cytoplasm type, associated with random field test cross test for the ' $\mathrm{B}$ ' line identification.

The goal of this study was to identify the cytoplasmic types present in 59 onion genotypes from the Embrapa Germplasm Bank, as well as the genotyping of the Ms locus, in order to reduce the time in the identification of male-sterile ('A') lines and maintainers of male sterility ('B'), an essential step in the process of obtaining hybrids.

\section{MATERIAL AND METHODS}

\section{Plant material}

Fifty-nine genotypes of the Embrapa Onion Germplasm Bank, consisting of 28 genotypes of Brazilian origin, 11 pairs worked for ' $A$ ' and 'B' lines, and 9 genotypes of different origin (Tables 1, 2, and 3) were evaluated. The genotype plants were sown in the experimental field of Embrapa Semiarid and transplanted when they reached $20 \mathrm{~cm}$ in height. The collection for DNA extraction was performed 30 days after transplanting, in young and healthy leaves. Leaves of seven plants of each genotype were collected and conditioned in the freezer at $-80^{\circ} \mathrm{C}$ until the individual extraction of the DNA.

\section{Evaluation of the type of cytoplasm}

The extraction of genomic DNA was done using the 2X CTAB protocol (Doyle and Doyle, 1990), with some modifications: 7500 and 10,000 rpm, in the first and second centrifugations, $2 \% \beta$-mercaptoethanol, and incubation at $60^{\circ} \mathrm{C}$ for $30 \mathrm{~min}$. The DNA was resuspended in TrisEDTA buffer, and DNA integrity and quantification was evaluated on $0.8 \%$ agarose gel.

Three independent PCRs were performed to identify the type of cytoplasm. The first two reactions were performed according to Engelke et al. (2003), with modifications, for the 5' cob and orfA501 markers, to a final volume of $20 \mu \mathrm{L}: 0.25 \mu \mathrm{M}$ of each primer, $0.15 \mathrm{mM}$ of each dNTP, 1X PCR buffer, $2.0 \mathrm{mM} \mathrm{MgCl}, 2.5 \mathrm{U}$ enzyme Taq DNA polymerase, and $50 \mathrm{ng}$ total DNA. The third reaction was performed according to Kim et al. (2009), for the orf725 marker, to a final volume of $10 \mu \mathrm{L}: 0.2 \mu \mathrm{M}$ of each primer, $0.2 \mathrm{mM}$ of each dNTP, 1X PCR buffer, $2.0 \mathrm{mM} \mathrm{MgCl}_{2}, 1.0 \mathrm{U}$ Taq DNA polymerase enzyme, and $50 \mathrm{ng}$ total DNA.

The primer sequences of the 5' cob marker (Sato, 1998) were: 1) primer S: 5'-GTCCA GTTCCTATAGAACCTATCACT-3', 2) primer N: 5'-TCTAGATGTCGCATCAGTGGAATC C-3', and 3) primer common: 5'-CTTTTCTATGGTGACAACTCCTCTT-3', which amplify the 180- and 414-bp fragments. The second reaction was with primers from the orfA501 marker (Engelke et al., 2003): primer 1: 5'-ATGGCTCGCCTTGAAAGAGAGC-3' and primer 2: 5'-CCAAGCATTTGGCGCTGAC-3', which amplifies the 473-bp fragment. The results of these two reactions were considered as complementary in the identification of cytoplasmic types. The third reaction was performed with the primers of the orf 725 marker: 1) MK-F: 5'-CATAGGCGGGCTCACAGGAATA-3', 2) MK-R1: 5'-AATCCTAGTGTCCGGGGTTTC T-3', and 3) MK-R2: 5'-CAGCGAACTTTCATTCTTTCGC-3' developed by Kim et al. (2009).

Genetics and Molecular Research 16 (3): gmr16039766 
These primers amplify fragments of 628 and $833 \mathrm{bp}$.

The programming of the thermocycler for 5' $c o b$ amplifications consisted of: a) an initial cycle of $2 \mathrm{~min}$ at $94^{\circ} \mathrm{C}$, b) 36 cycles of $30 \mathrm{~s}$ at $94^{\circ} \mathrm{C}, 1 \mathrm{~min}$ at $53^{\circ} \mathrm{C}$ and $2 \mathrm{~min}$ at $72^{\circ} \mathrm{C}$, and c) a final cycle of $5 \mathrm{~min}$ at $72^{\circ} \mathrm{C}$. The orf A501 marker consisted of: a) an initial cycle of 2 min at $94^{\circ} \mathrm{C}$, b) 40 cycles of $30 \mathrm{~s}$ at $94^{\circ} \mathrm{C}, 1 \mathrm{~min}$ at $54^{\circ} \mathrm{C}, 2$ min at $72^{\circ} \mathrm{C}$, and c) one cycle end of 5 min at $72^{\circ} \mathrm{C}$. For the $\operatorname{orf} 725$ marker, the following were followed: a) an initial denaturation cycle of $5 \mathrm{~min}$ at $94^{\circ} \mathrm{C}$, b) 40 cycles of $30 \mathrm{~s}$ at $94^{\circ} \mathrm{C}, 1 \mathrm{~min}$ at $60^{\circ} \mathrm{C}$ and $90 \mathrm{~s}$ at $72^{\circ} \mathrm{C}$, and c) a final cycle of $5 \mathrm{~min}$ at $72^{\circ} \mathrm{C}$.

PCR products were visualized on $1.5 \%$ agarose gels stained with ethidium bromide and photographed under ultraviolet light. The identification of ' $\mathrm{N}$ ', ' $\mathrm{S}$ ', and ' $\mathrm{T}$ ' cytoplasms for the 5' cob and orfA501 markers was based on Engelke et al. (2003): 1) 'N' cytoplasm presence of a 180-bp fragment and absence of other fragments; 2) 'S' cytoplasm - presence of fragments of 180, 414, and $473 \mathrm{bp}$; and 3) ' $\mathrm{T}$ ' cytoplasm - presence of the 180- and 473-bp fragments and absence of the 414-bp fragment. For the orf 725 marker, it was identified as ' $\mathrm{N}$ ' cytoplasm the presence of a fragment of $833 \mathrm{bp}$, as ' $\mathrm{T}$ ' cytoplasm the presence of fragments of 833 and $628 \mathrm{bp}$, and as ' $S$ ' cytoplasm the presence of a fragment of $628 \mathrm{bp}$. The size of the amplified fragments was estimated in comparison with the 100-bp Ladder marker.

\section{Evaluation of the male-fertility restorer locus $(M s)$}

PCRs for the codominant marker AcSKP1 (Huo et al., 2015) were adjusted to a final volume of $25 \mu \mathrm{L}$ : $50 \mathrm{ng}$ total DNA, $0.4 \mu \mathrm{M}$ FU 898 (5'-GCAATACACAGCTTCTAGCTGA ATT-3'), $0.4 \mu \mathrm{M}$ FD 898 (5'-AACACACACACAGAGTGAGAAATTTTATAT-3'), $0.2 \mu \mathrm{M} \mathrm{SU}$ 628 (5'-TCTGTGTGTGTGTGTAATTTCTCTG-3'), $0.2 \mu \mathrm{M}$ SD 628 (5'-CGGAAGATTAAT ATTTTGCGTATACAT-3'), $0.15 \mathrm{mM}$ of each dNTP, 1 X PCR buffer, $2.0 \mathrm{mM} \mathrm{MgCl}$ and 2.0 U Taq DNA polymerase enzyme. For the AcPMS1 marker (Kim et al., 2015), the amplification reactions were adjusted to a final volume of $10.0 \mu \mathrm{L}$ : $10 \mathrm{ng}$ total DNA, $0.2 \mu \mathrm{M}$ of the primer forward (5'-GGTCACCAGGTGGAGAGAGAA-3'), $0.2 \mu \mathrm{M}$ of the primer reverse (5'-TCATTGAGCTGCATCCAAAA-3'), $0.2 \mathrm{mM}$ of each dNTP, 1X PCR buffer, $2.0 \mathrm{mM}$ $\mathrm{MgCl}_{2}$ and $1 \mathrm{U}$ Taq DNA polymerase. The amplification reactions for the marker AcSKP1 were described by Huo et al. (2015) and Kim et al. (2015). The amplified products were separated on $1.5 \%$ agarose gels for the AcSKP1 marker and on 2.5\% gels for the AcPMS1 marker, both stained with ethidium bromide and photographed under ultraviolet light.

The evaluation for the locus fertility restorer of the marker AcSKP1 considered: 1) dominant homozygote $(M s M s)$ - presence of an 898-bp fragment, 2) recessive homozygous

(msms) - presence of a 628-bp fragment, and 3) heterozygote (Msms) of 898- and 628-bp fragments (Huo et al., 2015). For the AcPMS1 marker we considered: 1) dominant homozygote $(M s M s)$ - a 242-bp fragment, 2) homozygous recessive (msms) - a 276-bp fragment, and 3) heterozygous (Msms) - the presence of fragments of 242 and $276 \mathrm{bp}$. The size of the fragments was estimated in comparison with the marker with the 100-bp ladder.

\section{RESULTS}

\section{Evaluation of the type of cytoplasm}

The two types of male-sterile cytoplasm ('S' and ' $\mathrm{T}$ '), as well as the fertile cytoplasm

Genetics and Molecular Research 16 (3): gmr16039766 
('N'), were detected in the 59 genotypes evaluated (Tables 1, 2, and 3). The gels were readily identifiable for all 5' cob/orfA501 and orf 725 markers, producing fragments of the expected sizes, as Engelke et al. (2003) and Kim et al. (2009) (Figures 1 and 2).

\begin{tabular}{|c|c|c|c|c|c|c|c|c|}
\hline \multirow[t]{2}{*}{ Genotype } & \multirow{2}{*}{\begin{tabular}{|l|} 
Cytoplasm \\
Marker
\end{tabular}} & \multicolumn{3}{|c|}{ Cytoplasm } & \multirow{2}{*}{\begin{tabular}{|l} 
Restorer \\
Marker
\end{tabular}} & \multicolumn{3}{|c|}{ Genotyping } \\
\hline & & $\mathrm{N}$ & $\mathrm{S}$ & $\mathrm{T}$ & & $M s M s$ & Msms & $m s m s$ \\
\hline \multirow[t]{2}{*}{ Serrana } & 5' cob/orfA501 & 2 & 0 & 5 & AcSKP1 & 5 & 1 & 1 \\
\hline & orf 725 & 4 & 0 & 3 & AcPMS1 & 5 & 1 & 1 \\
\hline \multirow[t]{2}{*}{ Regia } & 5'cob/orfA501 & 5 & 1 & 1 & AcSKP1 & 0 & 1 & 6 \\
\hline & orf 725 & 5 & 1 & $\frac{1}{1}$ & AcPMS1 & 0 & $\frac{1}{1}$ & 6 \\
\hline \multirow[t]{2}{*}{ EHCEB 20146} & 5'cob/orfA501 & 1 & 3 & 3 & AcSKP1 & 3 & 2 & 2 \\
\hline & orf 725 & 1 & 3 & 3 & AcPMS1 & 3 & 2 & 2 \\
\hline \multirow{2}{*}{ Crioula Mercosul } & 5'cob/orfA501 & 1 & 0 & 6 & AcSKP1 & 1 & 3 & 3 \\
\hline & orf 725 & 4 & 0 & 3 & AcPMS1 & 1 & 3 & 3 \\
\hline \multirow{2}{*}{ Primavera } & 5'cob/orfA501 & 7 & 0 & 0 & AcSKP1 & 0 & 0 & 7 \\
\hline & orf 725 & 7 & 0 & 0 & AcPMS1 & 0 & 0 & 7 \\
\hline \multirow[t]{2}{*}{ EHCEB 201426} & 5'cob/orfA501 & 0 & 7 & 0 & AcSKP1 & 3 & 4 & 0 \\
\hline & orf 725 & 0 & 7 & 0 & AcPMS1 & 3 & 4 & 0 \\
\hline \multirow[t]{2}{*}{ EHCEB 20142} & 5'cob/orfA501 & 3 & 0 & 4 & AcSKP1 & $\frac{3}{1}$ & 4 & 2 \\
\hline & orf 725 & 1 & 0 & 6 & AcPMS1 & $\frac{1}{1}$ & $\frac{4}{4}$ & 2 \\
\hline \multirow[t]{2}{*}{ Bola Precoce } & 5' cob/orfA501 & 0 & 0 & 7 & AcSKP1 & 4 & 3 & 0 \\
\hline & orf725 & 1 & 0 & 6 & AcPMS1 & 4 & 3 & 0 \\
\hline \multirow[t]{2}{*}{ EHCEB 201427} & 5' cob/orfA501 & $\frac{1}{2}$ & 2 & 3 & AcSKP1 & $\frac{4}{1}$ & 2 & 4 \\
\hline & $\begin{array}{l}\text { orf } 725 \\
\text { orforgAs01 }\end{array}$ & 2 & 2 & 3 & AcPMS1 & $\frac{1}{1}$ & $\frac{2}{2}$ & 4 \\
\hline \multirow[t]{2}{*}{ Alvorada } & 5' cob/orfA501 & 4 & 1 & 1 & AcSKP1 & $\frac{1}{1}$ & 5 & $\frac{4}{1}$ \\
\hline & orf 725 & 4 & $\begin{array}{l}1 \\
1\end{array}$ & $\frac{1}{1}$ & AcPMS1 & $\frac{1}{1}$ & 4 & $\frac{1}{1}$ \\
\hline \multirow[t]{2}{*}{ Roxa Barreiro } & 5' cob/orfA501 & 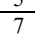 & $\begin{array}{l}1 \\
0\end{array}$ & $\frac{1}{0}$ & AcSKP1 & 4 & 2 & $\frac{1}{1}$ \\
\hline & orf 725 & 7 & 0 & 0 & AcPMS1 & 3 & 2 & $\frac{1}{1}$ \\
\hline Conquista & 5'cob/orfA501 & 6 & 0 & 0 & AcSKP1 & 5 & 1 & 0 \\
\hline & orf 725 & 6 & 1 & 0 & AcPMS1 & 6 & 1 & 0 \\
\hline Imperatriz & 5' cob/orfA501 & 0 & 7 & 0 & AcSKP1 & 1 & 3 & 1 \\
\hline & orf725 & 0 & 7 & 0 & AcPMS1 & 1 & 3 & 1 \\
\hline São Paulo & 5'cob/orfA501 & 0 & 0 & 6 & AcSKP1 & 3 & 1 & 3 \\
\hline & orf 725 & 0 & 0 & 7 & AcPMS1 & 2 & 1 & 2 \\
\hline BRS 367 & 5'cob/orfA501 & 3 & 0 & 4 & AcSKP1 & 0 & 2 & 3 \\
\hline & orf 725 & 3 & 0 & 3 & AcPMS1 & 0 & 3 & 3 \\
\hline Rainha & 5' cob/orfA501 & 6 & 0 & 1 & AcSKP1 & 4 & 2 & 1 \\
\hline & orf 725 & 6 & 0 & 1 & AcPMS1 & 4 & 2 & 1 \\
\hline Juporanga & 5' cob/orf A501 & 6 & 0 & 1 & AcSKP1 & 5 & 1 & 1 \\
\hline & orf 725 & 6 & 0 & 1 & AcPMS1 & 5 & 1 & 1 \\
\hline Cascuda T8 & 5' cob/orf A501 & 0 & 3 & 4 & AcSKP1 & 1 & 3 & 3 \\
\hline & orf 725 & 0 & 3 & 4 & AcPMS1 & 2 & 2 & 3 \\
\hline Cascuda T7 & 5'cob/orfA501 & 7 & 0 & 0 & AcSKP1 & 3 & 3 & 1 \\
\hline & orf 725 & 7 & 0 & 0 & AcPMS1 & 2 & 3 & 1 \\
\hline Cascuda T6 & 5'cob/orfA501 & 7 & 0 & 0 & AcSKP1 & 2 & 4 & 1 \\
\hline & orf 725 & 7 & 0 & 0 & AcPMS1 & 2 & 4 & $\frac{1}{1}$ \\
\hline Cascuda T5 & 5'cob/orfA501 & 0 & 7 & 0 & AcSKP1 & 4 & 2 & $\frac{1}{1}$ \\
\hline & orf 725 & 0 & 7 & 0 & AcPMS1 & 3 & 3 & 1 \\
\hline Cascuda T4 & 5' cob/orfA501 & 0 & 7 & 0 & AcSKP1 & 3 & 4 & 0 \\
\hline & orf 725 & 0 & 7 & 0 & AcPMS1 & 3 & 3 & 0 \\
\hline Cascuda T3 & 5'cob/orfA501 & 7 & 0 & 0 & AcSKP1 & 5 & $\frac{3}{1}$ & 1 \\
\hline & orf 725 & 7 & 0 & 0 & AcPMS1 & 5 & 1 & 1 \\
\hline Cascuda T2 & 5'cob/orfA501 & 0 & 7 & 0 & AcSKP1 & 3 & 3 & 1 \\
\hline & orf 725 & 0 & 7 & 0 & AcPMS1 & 3 & 2 & 1 \\
\hline Alfa SF C-XI & 5' cob/orfA501 & 3 & 0 & 4 & AcSKP1 & 2 & 2 & 3 \\
\hline & orf 725 & 0 & 1 & 6 & AcPMS1 & $\frac{2}{2}$ & $\frac{2}{1}$ & 2 \\
\hline IPA 12 & 5' cob/orfA501 & 0 & 1 & 0 & AcSKP1 & 4 & $\frac{1}{2}$ & $\frac{2}{1}$ \\
\hline & orf 725 & 0 & 7 & 0 & AcPMS1 & $\frac{4}{2}$ & $\frac{2}{1}$ & $\frac{1}{2}$ \\
\hline IPA 11 & 5' cob/orfA501 & 7 & 0 & 0 & AcSKP1 & 0 & $\frac{1}{2}$ & 5 \\
\hline & orf 725 & 6 & 0 & 0 & AcPMS1 & 0 & 2 & 5 \\
\hline IPA 10 & 5'cob/orfA501 & 7 & 0 & 0 & AcSKP1 & 0 & $\frac{2}{1}$ & 6 \\
\hline & orf 725 & 7 & 0 & 0 & AcPMS1 & 0 & 1 & 6 \\
\hline
\end{tabular}

Genetics and Molecular Research 16 (3): gmr16039766 


\begin{tabular}{|c|c|c|c|c|c|c|c|c|}
\hline \multirow[t]{2}{*}{ Genotype } & \multirow{2}{*}{\begin{tabular}{|l|} 
Cytoplasm \\
Marker \\
\end{tabular}} & \multicolumn{3}{|c|}{ Cytoplasm } & \multirow{2}{*}{\begin{tabular}{|l|} 
Restorer \\
marker
\end{tabular}} & \multicolumn{3}{|c|}{ Genotyping } \\
\hline & & $\mathrm{N}$ & $\mathrm{S}$ & $\mathrm{T}$ & & $M s M s$ & Msms & $m s m s$ \\
\hline \multirow{2}{*}{ EHCEB 20142038} & 5' cob/orf A501 & 6 & 0 & 0 & AcSKP1 & 3 & 3 & 1 \\
\hline & orf725 & 7 & 0 & 0 & AcPMS1 & 3 & 3 & 1 \\
\hline \multirow[t]{2}{*}{ EHCEB 20141038} & 5' cob/orf A501 & 0 & 7 & 0 & AcSKP1 & 0 & 3 & 3 \\
\hline & orf725 & 0 & 7 & 0 & \begin{tabular}{|l|} 
AcPMS1 \\
\end{tabular} & 0 & 4 & 3 \\
\hline \multirow[t]{2}{*}{ EHCEB 20112036} & 5' cob/orfA501 & 7 & 0 & 0 & AcSKP1 & 0 & 1 & 6 \\
\hline & orf 725 & 7 & 0 & 0 & AcPMS1 & 0 & 1 & 6 \\
\hline \multirow[t]{2}{*}{ EHCEB 20111036} & 5' cob/orfA501 & 0 & 7 & 0 & AcSKP1 & 0 & 0 & 7 \\
\hline & orf725 & 0 & 7 & 0 & AcPMS1 & 0 & 0 & 5 \\
\hline \multirow[t]{2}{*}{ EHCEB 20142040} & 5' cob/orfA501 & 7 & 0 & 0 & AcSKP1 & 0 & 0 & 6 \\
\hline & orf 725 & 7 & 0 & 0 & AcPMS1 & 0 & 0 & 7 \\
\hline \multirow[t]{2}{*}{ EHCEB 20141040} & 5' cob/orf A501 & 0 & 7 & 0 & AcSKP1 & 0 & 0 & 7 \\
\hline & orf725 & 0 & 7 & 0 & AcPMS1 & 0 & 0 & 7 \\
\hline \multirow[t]{2}{*}{ EHCEB 20142027} & 5' cob/orf A501 & 6 & 0 & 0 & AcSKP1 & 0 & 0 & 7 \\
\hline & orf 725 & 7 & 0 & 0 & AcPMS1 & 0 & 0 & 7 \\
\hline \multirow[t]{2}{*}{ EHCEB 20141027 } & 5' cob/orfA501 & 0 & 0 & 7 & AcSKP1 & 0 & 0 & 7 \\
\hline & orf725 & 0 & 2 & 5 & AcPMS1 & 0 & 0 & 7 \\
\hline \multirow[t]{2}{*}{ EHCEB 20142028} & 5' cob/orf A501 & 7 & 0 & 0 & AcSKP1 & 0 & 0 & 7 \\
\hline & orf 725 & 7 & 0 & 0 & AcPMS1 & 0 & 0 & 6 \\
\hline \multirow[t]{2}{*}{ EHCEB 20141028} & 5' cob/orfA501 & 0 & 7 & 0 & AcSKP1 & 0 & 0 & 7 \\
\hline & orf725 & 0 & 7 & 0 & AcPMS1 & 0 & 0 & 7 \\
\hline \multirow{2}{*}{ EHCEB 20101003} & 5' cob/orf A501 & 0 & 0 & 7 & AcSKP1 & 0 & 0 & 7 \\
\hline & orf 725 & 0 & 2 & 5 & AcPMS1 & 0 & 0 & 7 \\
\hline \multirow[t]{2}{*}{ EHCEB 20122003} & 5' cob/orfA501 & 7 & 0 & 0 & AcSKP1 & 0 & 0 & 7 \\
\hline & orf 725 & 7 & 0 & 0 & AcPMS1 & 0 & 0 & 7 \\
\hline \multirow[t]{2}{*}{ EHCEB 20101019} & 5' cob/orfA501 & 0 & 0 & 7 & AcSKP1 & 0 & 1 & 6 \\
\hline & orf725 & 7 & 0 & 0 & AcPMS1 & 0 & 1 & 6 \\
\hline \multirow{2}{*}{ EHCEB 20102019} & 5' cob/orf A501 & 7 & 0 & 0 & AcSKP1 & 0 & 0 & 7 \\
\hline & orf725 & 7 & 0 & 0 & AcPMS1 & 0 & 0 & 7 \\
\hline \multirow[t]{2}{*}{ EHCEB 20101017} & 5' cob/orf A501 & 0 & 0 & 6 & AcSKP1 & 0 & 0 & 7 \\
\hline & orf 725 & 0 & 0 & 6 & AcPMS1 & 0 & 0 & 7 \\
\hline \multirow[t]{2}{*}{ EHCEB 20102017} & 5' cob/orfA501 & 6 & 0 & 1 & AcSKP1 & 0 & 2 & 5 \\
\hline & orf725 & 7 & 0 & 0 & AcPMS1 & 0 & 2 & 2 \\
\hline \multirow[t]{2}{*}{ EHCEB 20141008} & 5' cob/orfA501 & 1 & 0 & 6 & AcSKP1 & 0 & 0 & 7 \\
\hline & orf 725 & 1 & 0 & 6 & AcPMS1 & 0 & 0 & 7 \\
\hline EHCEB 20142008 & 5' cob/orf A501 & 7 & 0 & 0 & AcSKP1 & 0 & 0 & 6 \\
\hline & orf725 & 7 & 0 & 0 & AcPMS1 & 0 & 0 & 6 \\
\hline EHCEB 20111006 & 5' cob/orfA501 & 0 & 7 & 0 & AcSKP1 & 0 & 0 & 6 \\
\hline & orf 725 & 0 & 7 & 0 & AcPMS1 & 0 & 0 & 7 \\
\hline EHCEB 20112006 & 5' cob/orfA501 & 7 & 0 & 0 & AcSKP1 & 0 & 0 & 7 \\
\hline & orf 725 & 7 & 0 & 0 & AcPMS1 & 0 & 0 & 7 \\
\hline Alfa SF 'A' & 5' cob/orfA501 & 0 & 0 & 7 & AcSKP1 & 0 & 0 & 7 \\
\hline & orf725 & 0 & 0 & 7 & AcPMS1 & 0 & 0 & 7 \\
\hline Alfa SF 'B' & 5' cob/orfA501 & 7 & 0 & 0 & AcSKP1 & 0 & 0 & 7 \\
\hline & orf 725 & 7 & 0 & 0 & AcPMS1 & 0 & 0 & 7 \\
\hline
\end{tabular}

The frequencies of the ' $\mathrm{N}$ ', 'S' and ' $\mathrm{T}$ ' cytoplasm types in the Brazilian germplasm with the 5' cob/orfA501 markers were $0.47,0.28$, and 0.25 , respectively, whereas for orf 725 the frequencies were $0.47,0.27$, and 0.26 , respectively (Table 1 ). For ' $A$ ' and ' $B$ ' lines, the frequencies of ' $\mathrm{N}$ ', ' $\mathrm{S}$ ' and ' $\mathrm{T}$ ' for 5' cob/orf A501 were $0.50,0.23$, and 0.27 , respectively, while for $\operatorname{orf} 725$ the frequencies were $0.51,0.26$, and 0.23 , respectively (Table 2). For the germplasm of different origins, the frequencies of 5' cob/orfA501 and orf 725 were the same, being $0.25,0.72$, and 0.03 for ' $\mathrm{N}$ ', 'S', and ' $\mathrm{T}$ ', respectively (Table 3 ).

In the Brazilian germplasm, the classifications of the 5' cob/orfA501 and orf 725 markers were the same in 23 of the 28 genotypes (82\%) (Table 1). Changes in the frequencies of the 'N' and 'T' cytoplasms for Serrana, Crioula, EHCEB 20142, Bola Precoce, Rainha, Juporanga, and Alfa SF C-XI and small discrepancies between 'S' and ' $\mathrm{T}$ ' for Alfa SF C-XI were observed with the 5' cob/orfA501 and orf 725 markers (Table 1).

Genetics and Molecular Research 16 (3): gmr16039766 
Table 3. Fertile ' $N$ ' and male-sterile ' $S$ ' and ' $T$ ' cytoplasm types and genotyping for the male fertility (Ms) restorer locus in seven germplasm plants of diverse origin.

\begin{tabular}{|c|c|c|c|c|c|c|c|c|}
\hline \multirow[t]{2}{*}{ Genotype } & \multirow{2}{*}{\begin{tabular}{|l|} 
Cytoplasm \\
Marker \\
\end{tabular}} & \multicolumn{3}{|c|}{ Cytoplasm } & \multirow{2}{*}{\begin{tabular}{|l|} 
Restorer \\
Marker \\
\end{tabular}} & \multicolumn{3}{|c|}{ Genotyping } \\
\hline & & $\mathrm{N}$ & $\mathrm{S}$ & $\mathrm{T}$ & & $M s M s$ & Msms & Msms \\
\hline \multirow{2}{*}{ EHCEB 201525} & 5' cob/orfA501 & 0 & 7 & 0 & AcSKP1 & 2 & 3 & 2 \\
\hline & orf725 & 0 & 7 & 0 & AcPMS1 & 2 & 3 & 2 \\
\hline \multirow[t]{2}{*}{ EHCEB 201515} & 5' cob/orfA501 & 0 & 5 & 0 & AcSKP1 & 2 & 1 & 2 \\
\hline & orf725 & 0 & 5 & 0 & AcPMS1 & 2 & 1 & 2 \\
\hline \multirow[t]{2}{*}{ Optima F1 } & 5'cob/orfA501 & 0 & 7 & 0 & AcSKP1 & 0 & 0 & 7 \\
\hline & orf725 & 0 & 7 & 0 & AcPMS1 & 0 & 0 & 7 \\
\hline \multirow[t]{2}{*}{ Sirius F1 } & 5' cob/orfA501 & 0 & 7 & 0 & AcSKP1 & 2 & 3 & 2 \\
\hline & orf 725 & 0 & 7 & 0 & AcPMS1 & 2 & 3 & 2 \\
\hline F2 (EHCEB $20131006 \mathrm{x}$ & 5'cob/orfA501 & 0 & 7 & 0 & AcSKP1 & 2 & 3 & 1 \\
\hline EHCEB 20133014) & orf 725 & 0 & 7 & 0 & AcPMS1 & 2 & 3 & 1 \\
\hline F2 (EHCEB 20151030 $x$ & 5'cob/orfA501 & 0 & 7 & 0 & AcSKP1 & 1 & 5 & 1 \\
\hline EHCEB 20133015) & orf 725 & 0 & 7 & 0 & AcPMS1 & 1 & 5 & 1 \\
\hline \multirow[t]{2}{*}{ EHCEB 201124} & 5'cob/orfA501 & 6 & 1 & 0 & AcSKP1 & 4 & 2 & 1 \\
\hline & orf 725 & 6 & 1 & 0 & AcPMS1 & 4 & 2 & 1 \\
\hline \multirow[t]{2}{*}{ EHCEB 201513} & 5' cob/orfA501 & 5 & 0 & 2 & AcSKP1 & 7 & 0 & 0 \\
\hline & orf 725 & 5 & 0 & 2 & AcPMS1 & 7 & 0 & 0 \\
\hline \multirow[t]{2}{*}{ EHCEB 201423} & 5'cob/orfA501 & 4 & 3 & 0 & AcSKP1 & 0 & 1 & 6 \\
\hline & orf 725 & 4 & 3 & 0 & AcPMS1 & 0 & 1 & 6 \\
\hline
\end{tabular}

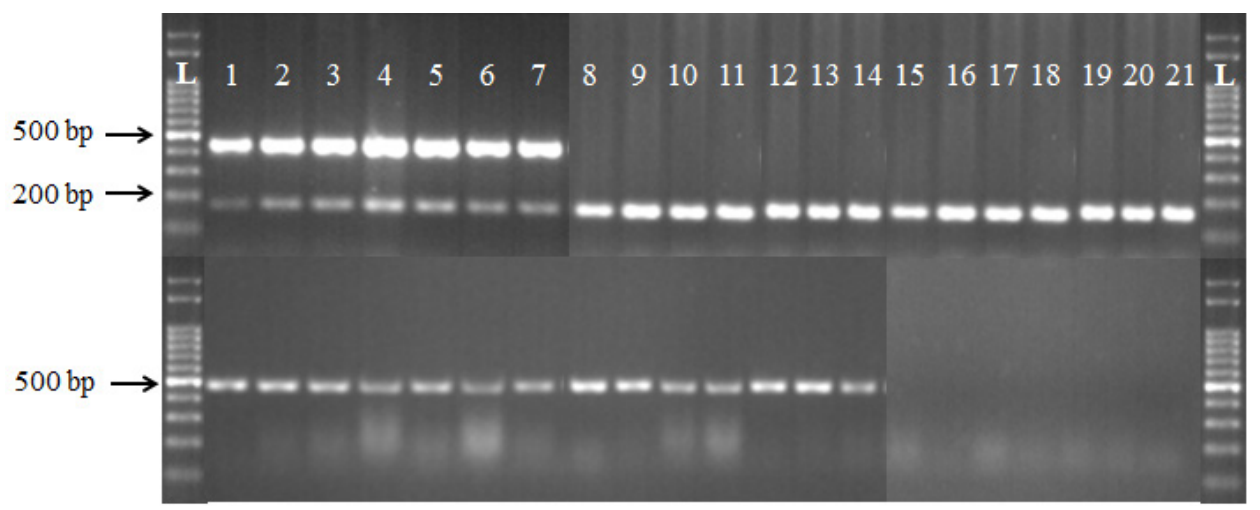

Figure 1. DNA fragments of 21 onion (Allium cepa L.) samples amplified with the primers of the 5' cob and orfA501 markers. Accession EHCEB 20111036 ('S' cytoplasm, fragments with 180, 414, and $473 \mathrm{bp}$ ) = lanes 1, 2, 3, 4, 5, 6, and 7. Accession Alfa SF 'A' ('T' cytoplasm, fragments with 180 and $473 \mathrm{bp}$ ) = lanes 8, 9, 10, 11, 12, 13, and 14. Accession Cascuda T5 (cytoplasm ' $\mathrm{N}$ ', fragments with $180 \mathrm{bp}$ ) =lanes 15, 16, 17, 18, 19, 20, and 21. Lane $L=$ a 100-bp ladder. Embrapa Semiárido, Petrolina, PE, Brasil, 2017.

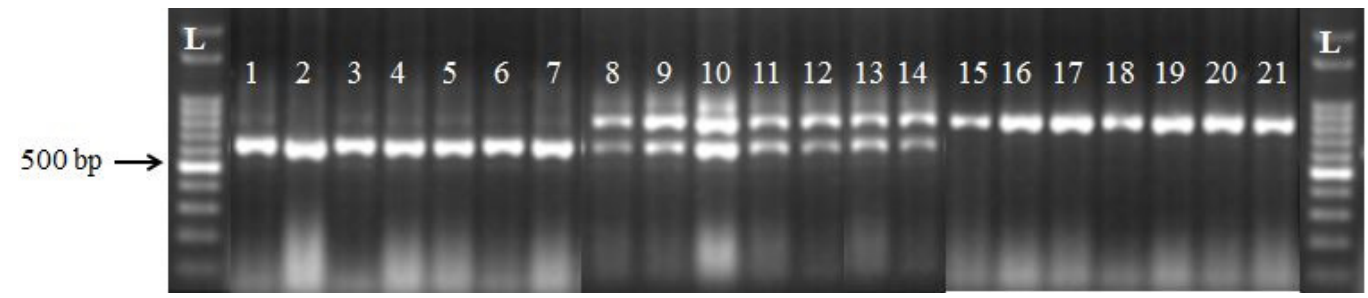

Figure 2. DNA fragments of 21 onion (Allium cepa L.) samples amplified with the orf 725 marker primers. Accession EHCEB 20111036 (' $\mathrm{S}$ ' cytoplasm, 628-bp fragments) = lanes 1, 2, 3, 4, 5, 6, and 7. Accession Alfa SF 'A' ('T' cytoplasm, fragments with 628 and $833 \mathrm{bp}$ ) = lanes 8, 9, 10, 11, 12, 13, and 14. Accession Cascuda T7 (cytoplasm 'N', fragments with $833 \mathrm{bp}$ ) = lanes 15, 16, 17, 18, 19, 20, and 21. Lane $L=$ a 100-bp ladder. Embrapa Semiárido, Petrolina, PE, Brasil, 2017. 
The genotypes Serrana, Regia, EHCEB 20146, Crioula Mercosul, EHCEB 20142, EHCEB 201427, Alvorada, BRS 367, Rainha, Juporanga, and Alfa SF C-XI presented a mixture of fertile (' $N$ ') and sterile (' $S$ ' and ' $T$ '), having potential for works aiming to identify lines ' $A$ ' and 'B' (Table 1). The other genotypes presented either single-type or mixed cytoplasm of the two sterile cytoplasms, with limitations to identify ' $A$ ' and ' $B$ ' lines within them (Table 1).

The ' $\mathrm{A}$ ' and ' $\mathrm{B}$ ' classifications with the 5' cob/orf A501 and orf725 markers were the same in 18 of the 22 lines (82\%) (Table 2). The lines EHCEB 20141027 and EHCEB 20101003 presented cytoplasmic type classification discrepancies, being classified as ' $\mathrm{T}$ ' by the 5 ' $\mathrm{cob} /$ orfA501 markers and as ' $\mathrm{S}$ ' by the orf725 marker. Changes in the frequencies of the ' $\mathrm{N}$ ' and 'T' cytoplasm were also observed for the EHCEB 20101019 and EHCEB 20102017 lines.

EHCEB 20142038/EHCEB 20141038, EHCEB 20112036/EHCEB 20111036, EHCEB 20142040/ EHCEB 20141040, EHCEB 20142028/EHCEB 20141028, and EHCEB 20112006/EHCEB 20111006 pairs presented ' $N$ ' cytoplasm in line 'B' and 'S' cytoplasm in line 'A' in all plants evaluated, whereas EHCEB 20101019/EHCEB 20102019, EHCEB 20101017/EHCEB 20102017 and Alfa SF 'A'/Alfa SF 'B' presented 'T' and 'N' cytoplasm, respectively (Table 2 ). The other 'A' and 'B' lines showed a cytoplasmic mixture within a line or different classification with the 5' cob/orfA501 and orf725 markers (Table 2).

In the germplasm of diverse origin, complete agreement was observed for the nine genotypes in both the classification and the frequency of the three types of cytoplasm evaluated with the markers 5' cob/orfA501 and orf 725 was 100\% (Table 3). Only the genotypes of different origin EHCEB 201124, EHCEB 201513, and EHCEB 201423 have the potential for identification of ' $\mathrm{A}$ ' and ' $\mathrm{B}$ ' lines, as they showed a mixture of fertile (' $\mathrm{N}$ ') and sterile (' $\mathrm{T}$ ' or 'S') cytoplasm (Table 3).

\section{Evaluation of the male-fertility restorer locus (Ms)}

The $M s$ and $m s$ alleles were detected in the 59 evaluated genotypes, both in homozygous and in heterozygous (Tables 1,2, and 3). The amplicons on the gels were easily identified for all markers with the two alleles, producing fragments of the expected sizes, according to Huo et al. (2015) and Kim et al. (2015) (Figures 3 and 4). Only in the reaction using the marker AcPMS1 (Kim et al., 2015) it was observed presence in some of the nonspecific band samples.

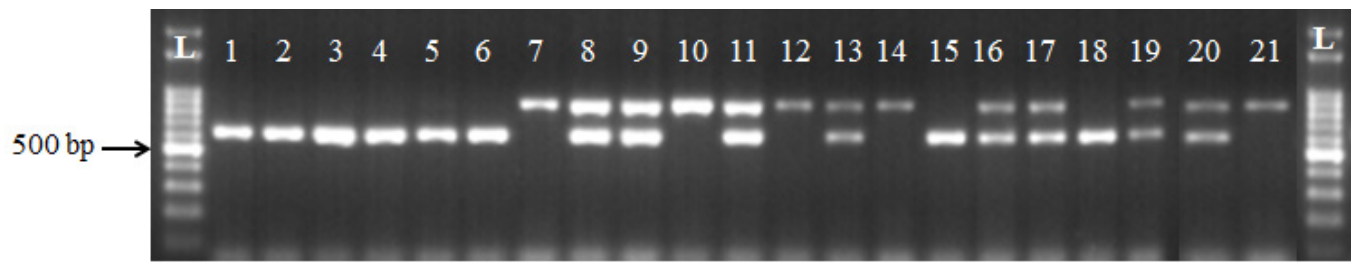

Figure 3. DNA fragments of 21 onion (Allium cepa L.) samples amplified with the marker AcSKP1. Accession Sirius F1 (recessive homozygote, fragments with $628 \mathrm{bp}$ ) =lanes 1, 2, 3, 4, 5, and 6. Accession Primavera (dominant homozygote, fragments with $898 \mathrm{bp}$ ) = lanes 7, 10, and 12 and (heterozygote, fragments with 628 and $898 \mathrm{bp})=$ lanes $8,9,11$, and 13. Accession EHCEB $20142($ dominant homozygote, fragments with $898 \mathrm{bp})=$ lane 14 (heterozygote, fragments with 628 and $898 \mathrm{bp}$ ) =lanes 16,17, 19, and 20 and (recessive homozygote, fragments with $628 \mathrm{bp}$ ) = lanes 15 and 18 . Accession Bola Precoce (dominant homozygote, fragment with $898 \mathrm{bp}$ ) =lane 21 . Lane $L=$ a 100-bp ladder. Embrapa Semiárido, Petrolina, PE, Brasil, 2017.

Genetics and Molecular Research 16 (3): gmr16039766 


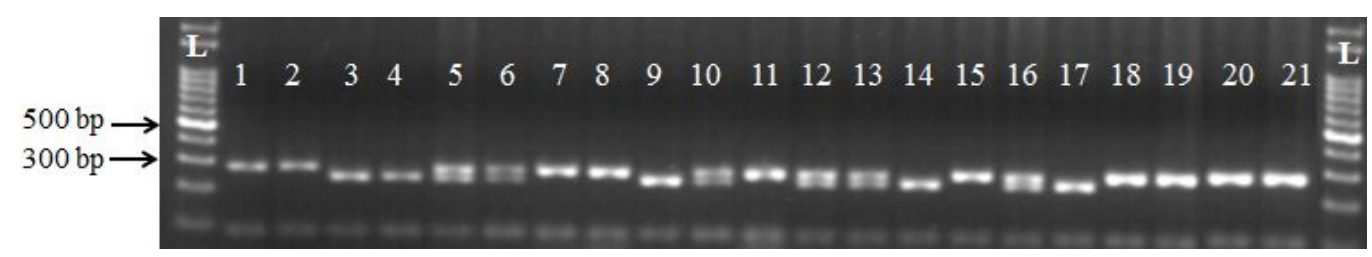

Figure 4. DNA fragments of 21 onion (Allium cepa L.) samples amplified with the marker AcPMS1. Accession EHCEB 20146 (recessive homozygote, fragments with $276 \mathrm{bp}$ ) = lanes 1 and 2 and (dominant homozygote, fragments with $242 \mathrm{bp}$ ) = lanes 3 and 4 . Accession Composto 1 (dominant homozygote, fragments with $242 \mathrm{bp})=$ lane 9 (heterozygous, fragments with 242 and $276 \mathrm{bp}$ ) = lanes 5, 6, and 10 and (recessive homozygote, with 276 bp fragments $)=$ lanes 7,8 , and 11 . Accession Crioula Mercosul (dominant homozygote, fragment with $242 \mathrm{bp})=$ lanes 14 and 17 (heterozygote, fragments with 242 and $276 \mathrm{bp}$ ) = lanes 12, 13, and 16 and (recessive homozygote, fragments with $276 \mathrm{bp}$ ) = lanes 15 and 18 . Accession Sirius F1 (recessive homozygote, fragment with $276 \mathrm{bp})=$ lanes 19, 20, and 21. Lane $L=$ a 100-bp ladder. Embrapa Semiárido, Petrolina, PE, Brasil, 2017.

The allelic and genotypic frequencies in the Brazilian germplasm were approximated with the markers AcSKP1 and AcPMS1, being 0.52 and 0.48 for $M s$ and $m s$, respectively, and $0.35,0.33$, and 0.32 for $M s M s, M s m s$, and $m s m s$, respectively (Table 1). Differences were observed in allelic and genotypic classifications only for the Conquista, Cascuda T8, and Cascuda T5 genotypes (Table 1).

The allele and genotype frequencies in ' $\mathrm{A}$ ' and ' $\mathrm{B}$ ' lines were approximated with the markers AcSKP1 and AcPMS1, being 0.06 and 0.94 for $M s$ and $m s$, respectively, and 0.02, 0.07 , and 0.91 for $M s M s, M s m s$, and $m s m s$, respectively (Table 2). The allelic and genotypic frequencies in germplasm of different origin were identical with the AcSKP1 and AcPMS1 markers, being 0.49 and 0.51 for $M s$ and $m s$, respectively, and $0.34,0.29$, and 0.37 for $M s M s$, Msms, and msms, respectively (Table 3).

\section{DISCUSSION}

The heterosis vigor, which results in high productive potential and greater bulbs uniformity of hybrids in relation to OPs, has resulted in the adoption of hybrids in several countries (Serra and Currah, 2002) and in the trend of onion breeding in the last 50 years in the USA, Europe, and Japan (Brewster, 2008). The development of markers for identification of the male-sterility maintaining nuclear locus $(\mathrm{ms})$, associated with markers for identification of fertile cytoplasm ('N') or male sterile (' $T$ ' and ' $S$ '), opens a new perspective on the development of hybrids, considering the selection of ' $A$ ' and ' $B$ ' lines within germplasm adapted to certain environments, such as the semi-arid region of Brazil.

In this study, the coincidence of the results obtained by the markers used for cytoplasmic identification was high, but some discrepancies were detected. The 5' cob/ orfA501 markers consider the $c o b$ gene sequence $($ Sato, 1998) in the differentiation between cytoplasmic types, whereas the orf725 marker is the cox I gene (Kim et al., 2009). However, both sequences may occur in stoichiometric quantities detectable in the same individual, which may generate discrepancies when comparing such markers, as those observed in the Conquista, Alfa SF C-XI, EHCEB 20141027, and EHCEB 20101003 accessions where there were frequency changes between the ' $\mathrm{S}$ ' and ' $\mathrm{T}$ ' cytoplasm. Kim et al. (2009) further stated that orf 725 amplification, which should only occur in the male-sterile cytoplasm, could also be

Genetics and Molecular Research 16 (3): gmr16039766 
detected in the ' $\mathrm{N}$ ' cytoplasm, indicating that the use of this marker may generate some degree of ambiguity in cytoplasmic classification.

Kim and Yoon (2010), based on analyses of the mitochondrial and chloroplast genomes, reported that different genes might be involved in the induction of sterility in the male sterile system in onion. The authors did not find any differences between the ' $T$ ' and ' $N$ ' cytoplasm, but significant differences were found between them regarding the CMS-S, suggesting that the CMS-T originated from the normal cytoplasm. This event could be associated with the differences found in the identification of cytoplasm by the markers used in this study.

Khar and Saini (2016) used three molecular markers to identify cytoplasm, among them 5' $c o b$ and orf725, reporting that no divergent results were found for the markers used. However, the authors reported only ' $\mathrm{N}$ ' and ' $\mathrm{S}$ ' cytoplasm, without confirming the results about the association of orfA501 with 5' cob. Thus, if the complete analysis were performed by the authors above, such as the one applied in this study, discrepancies could have been detected.

AcSKP1 (Huo et al., 2015) and AcPMS1 (Kim et al., 2015) markers related to the Ms locus fertility restorer in the CMS-S system, amplified fragments in individuals bearing ' $\mathrm{T}$ ' cytoplasm. These results coincide with those found by Kim (2014) who reported the presence of the $M s$ locus in individuals with cytoplasmic ' $\mathrm{T}$ ' type. For the author, the restoration of fertility in this cytoplasm may not be controlled by three independent genes, as proposed by Schweisguth (1973), but by the distortion of segregation of a single gene. In this way, the hypothesis is that the restoration is conferred by the same gene or by two strongly linked genes.

Khar and Saini (2016) reported equal frequencies of the $M s$ locus estimated by the AcSKP1 (Huo et al., 2015) and AcPMS1 (Kim et al., 2015) markers for the typically Indian germplasm, except line 121.1. In this study, applying the same markers in Brazilian germplasm, the same frequencies were observed, except for some small discrepancies in the genotypes Conquista, Cascuda T8, and Cascuda T5.

Genotypes that presented a mixture of cytoplasmic type, associated with recessive alleles for the restorative locus have great potential for selection of 'A' and 'B' lines. In this situation for the CMS-S system, of greater stability for hybrid production (Havey, 2000), four genotypes were identified in the Brazilian germplasm analyzed: Régia, EHCEB 20146, EHCEB 201427, and Alvorada. The genotypes EHCEB 20142040/EHCEB 20141040, EHCEB 20142028/EHCEB 20141028, and EHCEB 20112006/EHCEB 20111006 presented all plants in the condition Nmsms and Smsms, being considered lines 'B' and 'A', respectively, for the CMS-S system. Despite having a purity for the type of cytoplasm, the EHCEB 20142038/EHCEB 20141038 pair presented allelic mixture in lines 'B' and 'A', necessitating the elimination of the plants in the heterozygous condition, for total homozygous msms.

For the CMS-T system, 11 genotypes with the potential to obtain ' $\mathrm{A}$ ' and ' $\mathrm{B}$ ' lines were identified, considering a mixture of cytoplasm and msms plants: Serrana, Régia, EHCEB 20146, Crioula Mercosul, EHCEB 20142, EHCEB 201427, Alvorada, BRS 367, Rainha, Juporanga, and Alfa SF C-XI. The genotypes EHCEB 20142027/EHCEB 20141027, EHCEB 20102019/EHCEB 20101019, and Alfa SF 'B'/Alfa SF 'A' presented all plants in the condition Nmsms and Tmsms, being considered lines 'B' and 'A', respectively, for the CMS-T system. The Alfa SF 'A'/Alfa SF 'B' lines were previously identified by Santos et al. (2010), who adopted 5' cob/orfA501 molecular identification of male-sterile plants with random field pairing of fertile plants, followed by test cross.

In the CMS-T system, alleles of three genes in the male-sterile condition plants with ' $T$ ' cytoplasm are fertile if they have dominant allele $A$ or both dominant complementary alleles $C$

Genetics and Molecular Research 16 (3): gmr16039766 
and $D$ (Brewster, 2008). Because of this complex control, ' $\mathrm{B}$ ' lines (Nmsms) have been used as maintainers of 'A' lines on CMS-T (Pathak, 2000). Meer Van Der and Van Bennekom (1969) observed that the ' $\mathrm{T}$ ' cytoplasm might have temperature-affected sterility because when they analyzed a CMS-T lineage, they found $93 \%$ male-sterile plants at $14^{\circ} \mathrm{C}$ and only $10 \%$ at $23^{\circ} \mathrm{C}$.

The genotyping of OPs or lines previously worked for ' $\mathrm{A}$ ' and ' $\mathrm{B}$ ' lines for type of cytoplasm and nuclear locus $M S$ consists of an essential preliminary study to identify the most promising subjects that should follow for a later stage of study, evaluating a greater number of samples by genotypes and associating with pollen viability and test crosses to confirm the condition of male-sterile and male-sterile restorer plants.

OPs are still important in countries such as Brazil (Santos et al., 2010) and India (Khar and Saini, 2016). For Brewster (2008), the locally selected OPs are better suited to their region and may exceed the potential of hybrids developed in other regions. In this scenario, the identification of lines 'A' and 'B' within adapted OPs, such as the one carried out in the present study, may be the best situation for regions importing seeds of hybrids from other countries of different edaphoclimatic conditions.

\section{REFERENCES}

Brewster JL (2008). Onion and other vegetable alliums. 2nd edn. CAB International Wallingford, Cambridge.

Doyle JJ and Doyle JL (1990). Isolation of plant DNA from fresh tissue. Focus 12: 13-15.

Engelke T, Terefe D and Tatlioglu T (2003). A PCR-based marker system monitoring CMS-(S), CMS-(T) and (N)-cytoplasm in the onion (Allium cepa L.). Theor. Appl. Genet. 107: 162-167. https://doi.org/10.1007/s00122-003-1230-3

FAOSTAT (Food Agriculture Organization of the United Nations) (2017). Statistics: FAOSTAT-Agriculture. Available at [http://faostat.fao.org/site/339/default.aspx]. Accessed March 27, 2017.

Havey MJ (2000). Diversity among male-sterility-inducing and male-fertile cytoplasms of onion. Theor. Appl. Genet. 101: 778-782. https://doi.org/10.1007/s001220051543

Huo YM, Liu BJ, Yang YY, Miao J, et al. (2015). AcSKP1, a multiplex PCR-based co-dominant marker in complete linkage disequilibrium with the male-fertility restoration $(M S)$ locus, and its application in open-pollinated populations of onion. Euphytica 204: 711-722. https://doi.org/10.1007/s10681-015-1374-7

IBGE (Instituto Brasileiro de Geografia e Estatística) (2015). Levantamento Sistemático da Produção Agrícola. Available at [https://sidra.ibge.gov.br/home/lspa/brasil]. Accessed December 4, 2017.

Khar A and Saini N (2016). Limitations of PCR-based markers to identify male-sterile and maintainer plants from Indian onion (Allium cepa L.) populations. Plant Breed. 135: 519-524. https://doi.org/10.1111/pbr.12373

Khosa JS, McCallum J, Dhatt AS, Macknight RC, et al. (2016). Enhancing onion breeding using molecular tools. Plant Breed. 135: 9-20. https://doi.org/10.1111/pbr.12330

Kim S (2014). A codominant molecular marker in linkage disequilibrium with a restorer-of-fertility gene $M s$ and its application in reevaluation of inheritance of fertility restoration in onions. Mol. Breed. 34: 769-778. https://doi. org/10.1007/s11032-014-0073-8

Kim S and Yoon MK (2010). Comparison of mitochondrial and chloroplast genome segments from three onion (Allium cepa L.) cytoplasm types and identification of a trans-splicing intron of cox2. Curr. Genet. 56: 177-188. https://doi. org/10.1007/s00294-010-0290-6

Kim S, Lee ET, Cho DY, Han T, et al. (2009). Identification of a novel chimeric gene, orf725, and its use in development of a molecular marker for distinguishing among three cytoplasm types in onion (Allium cepa L.). Theor. Appl. Genet. 118: 433-441. https://doi.org/10.1007/s00122-008-0909-x

Kim S, Kim CW, Park M and Choi D (2015). Identification of candidate genes associated with fertility restoration of cytoplasmic male-sterility in onion (Allium cepa L.) using a combination of bulked segregant analysis and RNA-seq. Theor. Appl. Genet. 128: 2289-2299. https://doi.org/10.1007/s00122-015-2584-z

Leite DL (2012). Manejo e Conservação de Recursos Genéticos de Cebola (Allium cepa L.) na Embrapa Clima Temperado. Circular Técnica - Embrapa Clima Temperado 145: 1-7. Available at [https:/www.infoteca.cnptia.embrapa.br/ bitstream/doc/991096/1/circular145.pdf].

Meer Van Der QP and Van Bennekom JL (1969). Effect of temperature on the occurrence of male sterility in onion (Allium cepa L.). Euphytica 18: 389-394. https://doi.org/10.1007/BF00397786

Genetics and Molecular Research 16 (3): gmr16039766 
Nunes RLC, Oliveira AB and Dutra AS (2014). Agronomic performance of onion hybrids in Baraúna, in the semi-arid region of Brazil. Rev. Cienc. Agron. 45: 606-611. https://doi.org/10.1590/S1806-66902014000300023

Pathak CS (2000). Hybrid seed production in onion. J. New Seeds 1: 89-108. https://doi.org/10.1300/J153v01n03_04

Ragassi CF, Oliveira VR, Santos MDM, Boiteux MENF, et al. (2010). Identificação de citoplasma macho-estéril em acessos do programa de melhoramento de cebola da Embrapa Hortaliças. In: Anais do 50 Congresso Brasileiro de Olericultura, Guarapari.

Santos CAF, Leite DL, Costa ND, Oliveira VR, et al. (2008). Identificação dos citoplasmas "S", "T" e "N" via PCR em populações de cebola no Vale do São Francisco. Hortic. Bras. 26: 308-311. https://doi.org/10.1590/S010205362008000300003

Santos CAF, Leite DL, Oliveira VR, Rodrigues MA, et al. (2010). Marker-assisted selection of maintainer lines within an onion tropical population. Sci. Agric. 67: 223-227. https://doi.org/10.1590/S0103-90162010000200015

Santos CAF, Leite DL, Oliveira VR, Costa ND, et al. (2012). Identification of maintainer lines and evaluation of experimental hybrids derived from a brazilian tropical onion population. Acta Hortic. 935: 137-141. https://doi. org/10.17660/ActaHortic.2012.935.19

Sato Y (1998). PCR amplification of CMS-specific mitochondrial nucleotide sequences to identify cytoplasmic genotypes of onion (Allium cepa L.). Theor. Appl. Genet. 96: 367-370. https://doi.org/10.1007/s001220050750

Schweisguth B (1973). Étude d'un nouveau type de stérilité male chezl'oignon, Allium cepa L. Ann. Amelior. Plant. 23: 221-223.

Serra ADB and Currah L (2002). Agronomy of onions. In: Allium crop science: recent advances (Rabinowitch HD and Currah L, eds.). CABI Publishing, Wallingford.

Genetics and Molecular Research 16 (3): gmr16039766 